\section{Nina Karin Monsen}

Forfatter

Foto: NTB scanpix

\title{
Hjemmet som sykehus
}

\author{
Mange tror at det er best for syke \\ mennesker å være minst mulig \\ på sykehus, men være hjemme. \\ Også kronisk og alvorlig syke men- \\ nesker bør visst nok helst tilbringe \\ sin siste tid hjemme.
}

I årene fremover vil antakelig flere og flere pårørende pleie sine nærmeste hjemme. Kvinnene får de tyngste byrdene.

De praktiske, følelsesmessige og eksistensielle konsekvensene av dette er det få som diskuterer: Når sykehusene ikke tar seg av alvorlig, kronisk syke, må hjemmene bli sykehus. Alvorlig syke mennesker trenger den samme pleie og behandling uansett hvor de er. Pårørende må lære seg stell og behandling, lære om medisiner og deres virkninger. De må som amatører og uprofesjonelle lære å fremstå som sikre og mestrende overfor den syke. De må selv sette sine egne behov til side. De må være villige til å ta ansvar for behandlingen, hvilket innebærer at de må kunne tåle å gjøre feil. De bør være psykisk sterke og særdeles utholdende. Spesielt gjelder det når sykdommen er langvarig. De bør også helst bo i store og godt utstyrte leiligheter, og ha en romslig økonomi.

De fleste har antakelig opplevd en slik situasjon enten selv eller hos familie, venner og naboer. Min mann som døde for tre år siden, var alvorlig syk av langt fremskreden kols, noe jeg har skrevet om i boken Sorg og lidenskap, filosofiske refleksjoner. Vi var ikke kommet så langt at vårt hjem var blitt et sykehus, men det skyldes først og fremst at han ikke ba om eller fikk den behandlingen han burde fått. Hans dårlige tilstand var lett synlig og kronisk i mange år. Jeg levde med bekymring og angst. Ikke bare han, men også jeg burde hatt flere hjelpere. Men skulle jeg i tillegg administrere hans behandling, ville jeg hatt det mye verre.

Jeg ville ha vært meget usikker på hva jeg ville kunne komme til å gjøre av feil. Jeg har få medisinske kunnskaper. Jeg ville også fått problemer med å overbevise ham om at jeg var kompetent på området. Ved dødsfall i hjemmet må politiet tilkalles, det kan bli nødvendig med etterforskning. Hvem er rettslig ansvarlig for pasienten?

For eldre pårørende som selv har en del plager og sykdommer, kan livet bli ekstra tungt. De kan ikke som en sykepleier gå hjem til seg selv etter arbeidstid og legge byrdene fra seg. De har ikke noe annet hjem, får ingen fritid. De skal våke både dag og natt. $0 m$ de sover, våker de også. Hele tiden vil de observere den syke og notere seg forverring. De vil se etter døden, og kjenne at de lever i dødens forværelse. De vil kunne kjenne den ekstreme tyngden av det som skal komme, lenge før det kommer. Men de vet ikke, de bare aner.

Om de ikke er ekstremt dyktige til å fortrenge og glemme, kan det bli svært få hvilestunder. De blir mest sannsynlig trettere og trettere. Når døden kommer, kan den bli en ren lettelse. Den syke kan ha tatt all deres energi i årevis. De må lære ikke bare å sørge, men å glede seg over livet på nytt.

Vi hadde et samfunn der alvorlig syke mennesker hadde et selvfølgelig krav på en seng og profesjonelle hjelpere. Nå har vi et samfunn der de bare har et selvfølgelig krav på å sove i sin egen seng, eller i den dobbeltsengen de deler med sin nærmeste. De kan håpe på at hjemmesykepleierne kan komme når det er nødvendig. Fra livet på et sykehus der de i prinsippet kunne kjenne seg trygge og ha andre å dele skjebne med, må de leve livet der de selv blir sin nærmeste skjebne.

Jeg kjenner ikke til noen undersøkelse der alvorlig syke forteller om sin bekymring for sin nærmeste og dennes liv. Den kommer nok. Mange mennesker får det dårlig når de belaster andre som de er glade i. Mange vil ikke ligge andre til byrde. Slik har i hvert fall holdningen vært.

Noen har flere rundt seg, men de fleste i moderne tid har bare den andre. Etter hvert vil flere og flere ikke ha noen. Den etterlatte kan selv bli alvorlig syk. Enslige har ikke noe valg. De sendes også hjem fra sykehusene. Økonomien og rutinene avgjør. A d ø hjemme kan være et mulig valg for den som har gode nære rundt seg som tåler belastningen. Å d ø hjemme alene er neppe et ønsket valg for de fleste.

Samfunnsutviklingen er tydelig. Når hjemmene skal være våre sykehus og siste tilholdssted, blir vi alle pasienter når vi skal dele en pasients skjebne. For mange pårørende kan følgelig deres siste år, først med den kronisk og alvorlig syke, deretter i ensomhet med egen sykdom, bli unødig tunge og triste.

\section{Nira Karin Monsen}

